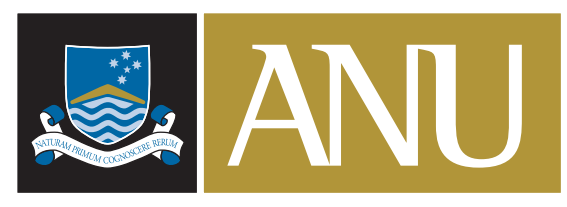

AUSTRALIA-JAPAN RESEARCH CENTRE

ANU COLLEGE OF ASIA \& THE PACIFIC

CRAWFORD SCHOOL OF ECONOMICS AND GOVERNMENT

\title{
INTERACTION BETWEEN TRADE, CONFLICT AND COOPERATION: \\ THE CASE OF JAPAN AND CHINA
}

Shiro Armstrong

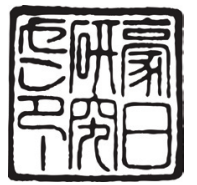

ASIA PACIFIC ECONOMIC PAPERS

No. 386, 2010 

ASIA PACIFIC ECONOMIC PAPER NO. 386

2010

\section{Interaction between trade, conflict and cooperation: the case of Japan and China}

Shiro Armstrong

AUSTRALIA-JAPAN RESEARCH CENTRE CRAWFORD SCHOOL OF ECONOMICS \& GOVERNMENT

ANU COLLEGE OF ASIA AND THE PACIFIC 
This work is copyright. Apart from those uses which may be permitted under the Copyright Act 1968 as amended, no part may be reproduced by any process without written permission.

Asia Pacific Economic Papers are published under the direction of the Editorial Committee of the Australia-Japan Research Centre (AJRC). Members of the Editorial Committee are:

Professor Jenny Corbett

Executive Director

Australia-Japan Research Centre

The Australian National University, Canberra

Professor Emeritus Peter Drysdale

Crawford School of Economics and Government

The Australian National University, Canberra

Professor Christopher Findlay

Professor of Economics

University of Adelaide

Adelaide, South Australia

Professor Stuart Harris

Department of International Relations

The Australian National University, Canberra

Dr Kazuki Onji

Crawford School of Economics and Government

The Australian National University, Canberra

Papers submitted for publication in this series are subject to double-blind external review by two referees. The views expressed in APEPs are those of the individual authors and do not represent the views of the Australia-Japan Research Centre, the Crawford School, or the institutions to which authors are attached.

The Australia-Japan Research Centre is part of the Crawford School of Economics and Government, The Australian National University, Canberra.

ISSN 07288409

ISBN 978-0-86413-340-3

Australia-Japan Research Centre

Crawford School of Economics and Government

The Australian National University

Canberra ACT 0200

Telephone: (61 2) 61253780

FACSIMILE: (61 2) 61258448

E-MAIL: AJRC@ANU.EDU.AU

URL: HTTP://WWW.CRAWFORD.ANU.EDU.AU 


\section{Interaction Between Trade, Conflict and Cooperation: The Case of Japan and China}

The complex interaction between trade and politics is analysed for the Japan-China relationship using Granger causality tests. The purpose is to determine the presence and direction of causation between trade and political events, both positive and negative, and to gauge an idea of the lag length of causality. Trade is growing quickly between Japan and China despite long standing political distance between the two countries. Results show that the economic relationship underpins and constrains the political relationship between Japan and China while an increase in positive political news and a decrease in negative political news promote trade to some degree.

JEL Classifications: C32; F10; F59

Keywords: Conflict and Cooperation; Japan-China; Trade; Granger Causality Contact: Crawford School of Economics and Government, Australian National University.

Email: shiro.armstrong@anu.edu.au

Acknowledgements: I am grateful to Peter Drysdale, Ligang Song, Jane Golley, Cezary Kapuscinski, Vikas Godara, Ryan Manuel, Bruce Chapman and Trevor Breusch for valuable comments and suggestions. Any errors are my own.

This article was the joint winner of the Australia-Japan Research Centre's Crawford Award in 2009. 


\section{Introduction}

The bilateral relationship between Japan and China is often characterised as one of 'cold politics' and 'hot economics'; the economic relationship continues to boom while historical issues and political tensions continue to strain the relationship.

After six years of suspended visits between leaders from 2001 to 2006, the period since late 2006 has seen an effort by both sides to mend relations, perhaps in recognition of the growing importance of their economic relationship. Since normalisation of diplomatic relations in 1972 and the period of the contemporary economic relationship since 1979, political tensions have at times deteriorated while the economic relationship continued to prosper.

Do political events have any effect on the trade relationship? Does increased trade and trade dependence cause countries to get along better? Or do the increased interactions through trade, or asymmetry in trade such as that seen in the United States-China case, cause political distance to widen and conflict to rise?

The view that increased trade and economic interdependence will result in a narrowing political distance is shared by many scholars and policy makers. ${ }^{1}$ There is also a view that increased imbalance in trade and economic interdependence will cause political tensions to rise.

This paper investigates the relationship between trade and political distance between China and Japan. The literature that studies the relationship between interstate relations (geopolitical relations) and economics (predominantly trade) use the terms 'conflict' and 'cooperation' to describe political distance. ${ }^{2}$ A political conflict is a widening of political distance and a cooperative event is a narrowing of political distance.

The paper looks at Japan's and China's relationships with their other major trading partner, the United States, as points of comparison. The expectation is that the economic relationship is interdependent with how well countries are getting along. The Japan-China relationship is expected to be different from both the United States-China and the United States-Japan relationships, the latter of which is a lot more stable politically.

Although the probability of war, or high-intensity conflict, between Japan and China is low, there are occasional flash points in the relationship such as Taiwan, disputed territorial claims and the legacy of history that have the potential to escalate. Extreme conflict (economic and trade sanctions, or even war) and high- level cooperation (such as through a customs union or security alliance) are at the opposite ends of the spectrum in a scale of conflict or cooperation events. These extremes do not occur in the China-Japan relationship over the period analysed in this study, but the relationship is one of low-intensity conflict and cooperation. 
China's relationship with its other major trading partner, the United States, is also complicated but does not perhaps share the historical complexity of the Japan-China relationship. The asymmetry in trade flows, stemming from the growing US bilateral trade deficit with China, has strained relations from time to time. On the other hand, the mutual recognition of the importance of the relationship, and the increased trade and interdependence, is causing the two to negotiate their way through the imbalance carefully and there are substantial efforts to keep relations stable.

A political distance variable is created in this study (consistent with other studies) by subtracting a scale of conflict from cooperation. Although not all events or news in the data are created by the actions of authorities on either side, and many are instead events that are a product of independent actors, they all have some positive or negative political impact. Thus, the index of net cooperation derived from the record of these events can serve as a measure of the political distance between the two countries in the study.

An alternative political distance variable, net conflict, which is a measure of conflict minus cooperation, is commonly used in the literature (Schneider et al., 2003). This differencing of the two variables imposes some limitations and assumptions on the event data and can potentially alter results, and is discussed later. A distinction is made between trade and economic interdependence in this study and, unlike in previous studies, both are tested for their correlation with the variables of net cooperation.

The study uses monthly data up to 2004, whereas previous studies (such as Reuveny, and Kang, 1998) for other countries have used quarterly data, analysed much earlier periods and not examined the relationship between Japan and China. Sub-periods of the data are analysed for the Japan-China relationship to capture any changing dynamics in the trade-cooperation relationship.

The next section sets out the main arguments in the trade-political distance debate and then reviews some of the growing empirical evidence supporting various arguments. The section after that provides a description and explanation of the political distance and trade data. Then the following section explains the Granger causality model, presents the estimation results and discusses other tests that were carried out for finding a robust relationship between the variables. Finally, the implications of the analysis are discussed before concluding. 


\section{Trade, conflict and cooperation}

There has been a rich debate for centuries about the link between political distance and economic interdependence (Mansfield and Pollins, 2003). In the last few decades, the debate has seen the growth of a vast amount of systematic empirical analysis which has added to the understanding of the issue but there remain many unanswered questions (Mansfield and Pollins, 2001). The broad line of thinking associated with the 'liberal' school is that as trade and interdependence between nations grow, there is a greater opportunity cost to conflict and so the chances of conflict are reduced. Another view point, associated with the realist school, argues that countries also go to war to acquire resources as an alternative to international trade. In addition, it is argued that asymmetries in trade relationships can cause tensions to rise. These views, and the supporting empirical evidence, are briefly reviewed below, as are other factors affecting the link between political distance and economic interdependence such as the proximity of countries and the level of their political liberalisation.

Economic interdependence can mean vulnerability towards another nation (for example, through exposure to a dominant resource or strategic goods supplier) and/or sensitivity to dependence (for example, through the effect of economic shocks such as inflation or exchange rate volatility in one country on another) and quite often trade flows are the best quantitative measure of these independencies that are available. ${ }^{3}$ There is, of course, a high correlation between trade and interdependence, as a large component of interdependence is due to trade; but interdependence will generally include other forms of trade, such as in services, as well as the flow of people and investment.

As early as 1748 Montesquieu, the French social commentator and political thinker, famously said:

\footnotetext{
Peace is the natural effect of trade. Two nations who traffic with each other become reciprocally dependent; for if one has an interest in buying, the other has an interest in selling: and thus their union is founded on their mutual necessities. -de Secondat (1748 [1989]: 316).
}

This is an insight that is often quoted in studies of interdependence and political distance. The basic idea is that mutual dependence leads to increased cooperation and a decrease in hostilities, or conflict. A narrowing of political distance has a positive relationship with interdependence or trade. This is an oft-cited and good characterisation of the liberal school of thought.

Trade flows are influenced significantly by broad political relations of amity and enmity between nations (Pollins, 1989b). The argument for a positive relationship between trade and cooperation runs both ways: trade fosters peace and peace fosters trade. As trade 
increases between two countries, the opportunity cost of conflict rises. Trade is seen as being driven by those fundamentals such as differences in factor endowments, but also significantly influenced by politics and the political distance between nations (Mansfield and Pollins, 2003). It is easy to see that allies may trade more and sign trade agreements (for example, the North American Free Trade Agreement) whereas in general, countries reduce or stop trade with their enemies (for example, the United States and Cuba).

Countries, and the actors within those countries that engage in trade, do so because they gain from it and it is in their interest to do so. Disputes and a widening of political distance may lead to a loss in trade and therefore a loss in welfare. Highly interdependent states rarely engage in full-blown war because the costs of doing so are too high.

Hirschman describes the politics of foreign trade and notes that there is 'the possibility of using trade as a means of political pressure...in the pursuit of power' (1945: xvi). The gains from trade between nations can have unequal distribution within countries as well as between countries (Hirschman, 1945). This unequal distribution of gains from trade can lead to a change in the structure of power within a country and between countries. Therefore, asymmetry in the gains from trade, which occurs quite naturally and regularly, can lead to a widening of political distance between countries and to high-intensity conflict in extreme cases especially if it causes a shift in power relations (Gilpin, 1981; Levy, 1989; Mearsheimer, 1990). Such views are representative of the realist school of thought. Liberal and realist views are not mutually exclusive, however, as a good example of the comfortable co-existence of the liberal and realist schools is Richard Nixon's opening up to China. Nixon was known as a realist but his opening up of relations with China was a liberal prescription.

An example of conflict (mainly low-intensity conflict) arising from asymmetric trade is the case of the United States and the trade disputes it has with some of its largest trade partners - Japan in the 1980s and the recent United States-China tensions over a rapidly growing bilateral trade imbalance.

There have been other characteristics identified that influence political distance. Countries with elected democracies, it is argued, do not go to war with each other ${ }^{4}$ (Kant, 1795; Wright, 1942); and there are ambiguous effects of enduring rivalries on the trade-political distance relationship.

Distance is very important in analysing the link between political distance and economic interdependence (O'Loughlin, 1993; Robst et al., 2006). On one hand, distance is an important determinant of trade and has been used extensively in gravity models of trade since Tinbergen (1962) to explain trade dependence. On the other hand, closer countries interact more with each other and neighbours tend to have more disputes (Vasquez, 1995). Further, neighbours may be more likely to have enduring rivalries (Stinnett and 
Diehl, 2001). The origin of such neighbourhood rivalries can include territorial disputes, disputes from increased trade (the closer countries are, the higher trade is, on average, as the gravity model attests) and the ability of countries to wage war on a neighbour as opposed to a distant country.

Of course, countries that trade often have many interactions and it is easy to see how even the closest of allies have disputes and low-intensity conflict from time to time. If the relationship of two countries is secure economically, incentives to create low-intensity conflict for domestic political reasons can arise. In fact, trade, or the threat of restrictions on trade, can be used as a signal to resolve disputes and avoid more serious conflict (Gartzke et al., 2001); so it is possible that trade can reduce military conflicts but increase non-military conflict, 'particularly if one country is more hesitant to fight' (Robst et al., 2006: 4). From this perspective, interdependence may foster a high degree of low-intensity conflict that is less likely to escalate (Gartzke, 1998).

To complicate matters, history is littered with counter-examples of adversaries trading during war time and countries changing the way they interact with the rest of the world. At first it is counter-intuitive to think of a widening of political distance or a negative action towards another country causing trade to increase, but there are examples in history, such as when Commodore Perry forced a then closed Japan to open its ports to international trade. Such examples are not common but are not anomalies.

Many studies do not recognise that the nature of the complex interactions between trade (or interdependence more broadly) and political distance change over time, both in intensity and direction, and that the relationship may depend on both domestic and international factors (Mansfield and Pollins, 2001).

\section{Empirical evidence}

Polachek (1978) was the first to analyse the relationship between trade and political distance with a cross-section study of the effect of trade on conflict. He found that increased trade reduces political distance, thus finding evidence of the liberal view. Polachek (1980) constructed a model from microeconomic foundations in an important paper showing the negative relationship between conflict and trade. His work generated a proliferation of empirical papers testing both realist and liberal theories.

While Polachek (1978) accounted for causality running from trade to political distance, Pollins (1989a, 1989b) is often recognised as the first to show the effect of political distance on trade in a single equation cross-section study. The importance of causality both ways between trade (or interdependence) and political distance has been recognised since Polachek (1980), and two-staged least squares regression models are used to estimate these relationships. Reuveny and Kang (2003) and Polachek (1997) have since derived 
simultaneous equations models.

Barbieri and Schneider (1999) contains a summary table of the main findings of the most significant empirical work in the field. It is clear from their review in the table that the results are mixed, methodologies are wide ranging, the countries covered differ, and in general, the time periods analysed are wide ranging. As Mansfield and Pollins (2001) make clear, conclusions often do not have sensible boundaries and are, more often than not, imprecisely stated as generalisations.

The most common political distance Data-sets used are events data such as the Cooperation and Peace Data Bank (COPDAB), World Events Interaction Survey (WEIS), and war Data-sets such as Militarised Interstate Disputes (MID) data, the latter of which are compiled by the Correlates of War Project. There is a stream in the literature testing the compatibility of many of these measures, the biases in the coding (King and Lowe, 2003 ) and whether these measures accurately reflect reality (Pevehouse, 2003). One such example shows the high level of compatibility between the COPDAB and WEIS Data-sets (Reuveny and Kang, 1996).

Barbieri (1996) finds strong evidence of economic interdependence increasing the likelihood of militarised interstate disputes. She finds this applies to symmetric as well as asymmetric interdependence between nations. In her study, the only form of interdependence that seems to mitigate conflict is low to moderate interdependence. Her data for conflicts is from 1870 to 1938 and she may have captured the different nature of interactions between countries in a different time from now. That was a time of imperial and colonial expansion and a less globalised world.

Robst et al. (2006) estimate the effects of geographical distance on political distance separately and find that trade reduces conflict to a greater extent when two countries are geographically close, but trade has a greater effect on cooperation when countries are distant. Closer countries have more interactions and there is more chance of territorial disputes and regional rivalries — both of which are relevant in analysing Japan and China. Robst et al. (2006) also find that proximity increases the number and severity of both conflict and cooperation events more among non-trading countries than countries with large trade. Their second finding does not relate to the study here, as Japan and China are close but trade is large. Robst et al. do find that although 'proximity provides incentives for conflict, trade mitigates these incentives' (2006: 5).

The literature suggests that the causality is bilateral-relationship dependent and the existence of causality often reciprocal - if political distance affects trade from country $\mathrm{X}$ to $\mathrm{Y}$, then often political distance will affect trade from country Y to X (Reuveny and Kang, 1998). If no causality is found in one direction of a bilateral relationship, then it is likely that no causality exists in the other direction. 
Results in the literature also point to causality running in different directions in different bilateral trade relationships, and the interactions depend on the type of traded good (for example, strategic goods versus non-strategic goods) (Reuveny and Kang, 1998).

Gasiorowski and Polachek (1982) and Reuveny and Kang (1996) test for Granger causality between conflict and trade using time series data. Gasiorowski and Polachek (1982) analyse Warsaw pact countries' trade with the United States and find relatively little evidence of Granger causality. Reuveny and Kang (1996) look at some of the most important and politically and economically significant relationships from the 1960s to early 1990s, concluding that the Granger causality is dependent on the relationships analysed and tends to be reciprocal. Similar methodology is used here for the Granger causality tests but with monthly data instead of quarterly data, with fewer relationships covered but in more detail.

To understand better how politics can affect trade, we take a look at an extreme case. A widening of political distance leading to a trade embargo or war will obviously affect trade adversely. The other extreme is that a customs union or high-level economic cooperation will increase trade. How does low-level political distance affect trade relations? A one-off territorial dispute may have little direct effect on trade, but it adds to perceived trade risk and increases overall country risk. The cumulative effects of continued lowintensity conflict will add to negative perceptions of, and attitudes towards, that country and over time political distance may widen. At the margin, it is to be expected that this can make a significant difference in the decision to undertake trade and other economic transactions.

Increased trade can foster cooperation and peace. Increased imbalances in trade or a shift in power relations sometimes due to trade can cause political distance to widen. Hence there is a feedback relationship from trade to political distance and vice versa. The implications of imbalanced and balanced trade will be important for the different cases of United States-China, where trade is largely imbalanced and United States-Japan, where trade is relatively balanced.

The literature reveals the interaction of political distance and economic relations is a complex one that depends on the countries, the symmetry in the economic relationship (level of trade) and the type of goods and FDI that flow between them. This paper will examine the data for causality relationships but the next section first introduces the data properly, which is important in understanding the analysis. 


\section{Data}

\section{Political distance events data}

The political distance variable used throughout this study is comprised of conflict/cooperation data from King's (2003) data-set of Integrated Data for Events Analysis (IDEA), which is an extension and refinement of the WEIS data set. ${ }^{5}$ There are more categories of conflict and cooperation in IDEA than in WEIS or COPDAB. Monthly bilateral conflict and cooperation variables for Japan-China, Japan-United States and United States-China were extracted for the period 1990-2004. A net cooperation variable is constructed by differencing conflict from cooperation, which is common in the literature, and called 'political distance'.

Cooperation is represented by positive events or positive political event in a relationship, generally from one country towards another. A report of 'Japan increasing overseas development aid (ODA) to China' would be a cooperative event from Japan towards China. Conflict is represented by a negative political or non-political event such as 'nation-wide protests in China against Japanese interests' or 'Japanese Prime Minister's visit to Yasukuni Shrine angers China'. For the net cooperation variable, a value of zero means no event or the weighted positive event (cooperation) has cancelled out the equally weighted negative event (conflict).

The events are machine coded from Reuters Business Briefs using Virtual Research Associates (VRA) software and the results are shown to be more accurate and consistent than high skill human coders (King and Lowe, 2003). The events covered report most actions from one country towards another, including such events categorised as comment, consult, approve, promise, grant, reward, agree, request, propose, reject, accuse, protest, deny, demand, warn, threaten and demonstrate. All events are given weights consistent with Goldstein (1992) to capture severity and extended from WEIS.

The assumption here is that a positive event will to some extent cancel out, or have the opposite effect on, a negative effect. The variables are analysed separately to confirm the importance of a net measure. Net conflict (conflict minus cooperation as opposed to the other way around) is used in other studies (Polachek, 1980; Pollins 1989a).

Figures 1 and 2 show the net cooperation indexes between Japan and China, and China and the United States for the sub-period 2002-2004 to illustrate what the data picks up and what the data looks like. The fifteen years from 1990 to 2004 cover many events and the sub-period is used here purely for illustration. Cooperation is positive and conflict is negative on the vertical axes in Figures 1 and 2. A move in the positive direction is a narrowing of political distance as countries become closer politically. A move in the 
negative direction from a conflict event is a widening of political distance.

Some of the peaks and troughs that can be noted from Figure 1 include:

\section{Cooperation}

- April 2002: National Peoples' Congress Chairman Li Peng meets Prime Minister Koizumi in Japan.

- August 2003: China and Japan participate and work together in six-party talks to solve the North Korean nuclear problem. Also there is news of FDI hitting record highs.

\section{Conflict}

- $\quad$ May 2002: diplomatic rift over North Korean asylum seekers

- July 2002: sunken North Korean ship in East China Sea creates tension between Japan and China

- December 2003: 400 Japanese businessmen organise an orgy in South China with 500 prostitutes. This is significant and shows up as such a large event because of ongoing discomfort over the war-time sex slavery.

- March 2004: Japan cuts aid to China by 20 per cent. There are also disputes over Senkaku/Diaoyu islands. These events lead to a cancellation of bilateral talks on a maritime treaty.

Figure 1 shows that the net cooperation index does not appear to pick up one of the most important and significant events between the two countries: the Yasukuni Shrine visits by Koizumi. The annual visits to the shrine between 2001 and 2006 created a great deal of tension as the shrine is supposed to house the spirits of 14 Class A war criminals and Koizumi's visits were very public and were seen by the Chinese public as honouring these war criminals. The visits during this sub-period took place on 21 April 2002, 14 January 2003 and 1 January 2004 but do not show up in the net cooperation index. The reason the shrine visits do not register in Figure 1 or in the net cooperation variable used in this study, is that the negative reportage of the shrine visit is cancelled out by positive cooperation news (such as record high FDI or trade numbers being reported). Indeed, if the conflict variable is viewed independently, the shrine visits do show up as significant conflict events (see Appendix A). The 2002 and 2003 visits are the most significant and the reasons for the 2001 and 2004 visits not showing up strongly even in the conflict data in those exact months are explained in Appendix A. 
No. 386,2010

Figure 1 Political distance (net cooperation) between Japan and China, 2002-04

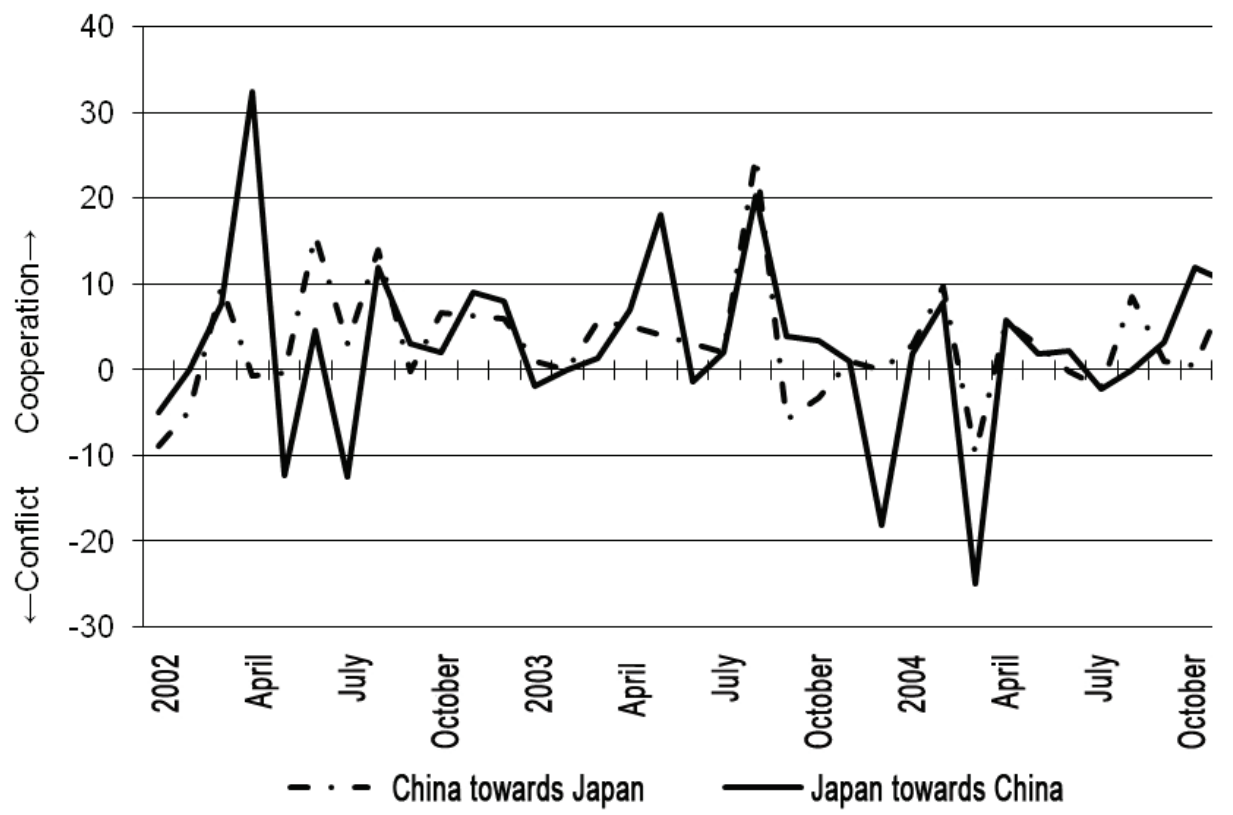

Note: Calculated as cumulative positive news scores less cumulative negative news scores.

Source: King (2003).

Also common in the literature is the use of relative conflict/cooperation rather than absolute conflict/cooperation to control for some countries having more events reported than others. Data-sets such as COPDAB which use the New York Times exclusively might bias the reporting of US events upwards, and no news source is bias free. Countries like the United States will naturally have more events as well, as they are engaged in more international activities and have more interactions with other countries. Converting the events into a relative measure by dividing the scale by the total number of events is not appropriate for this study because it will negate the fact that some countries interact more with other countries.

Some of the peaks and troughs from the US-China relationship in Figure 2 include:

\section{Cooperation}

- October 2002: China and the United States agree to work together on nuclear disarmament of North Korea.

- April 2004: Trade talks result in satisfactory outcome for both countries.

\section{Conflict}

- $\quad$ November 2003: Trade dispute leading to US antidumping measures being put 
in place on Chinese TVs, textiles, steel and soy beans (this is shown only as conflict from China towards the United States).

- July 2004: reports of avian influenza in China; China announces military manoeuvres in the Taiwan Straits and presses the United States to stop arms sales to Taiwan.

Figure 2 Political distance (net cooperation) between China and the United States, 2002-04

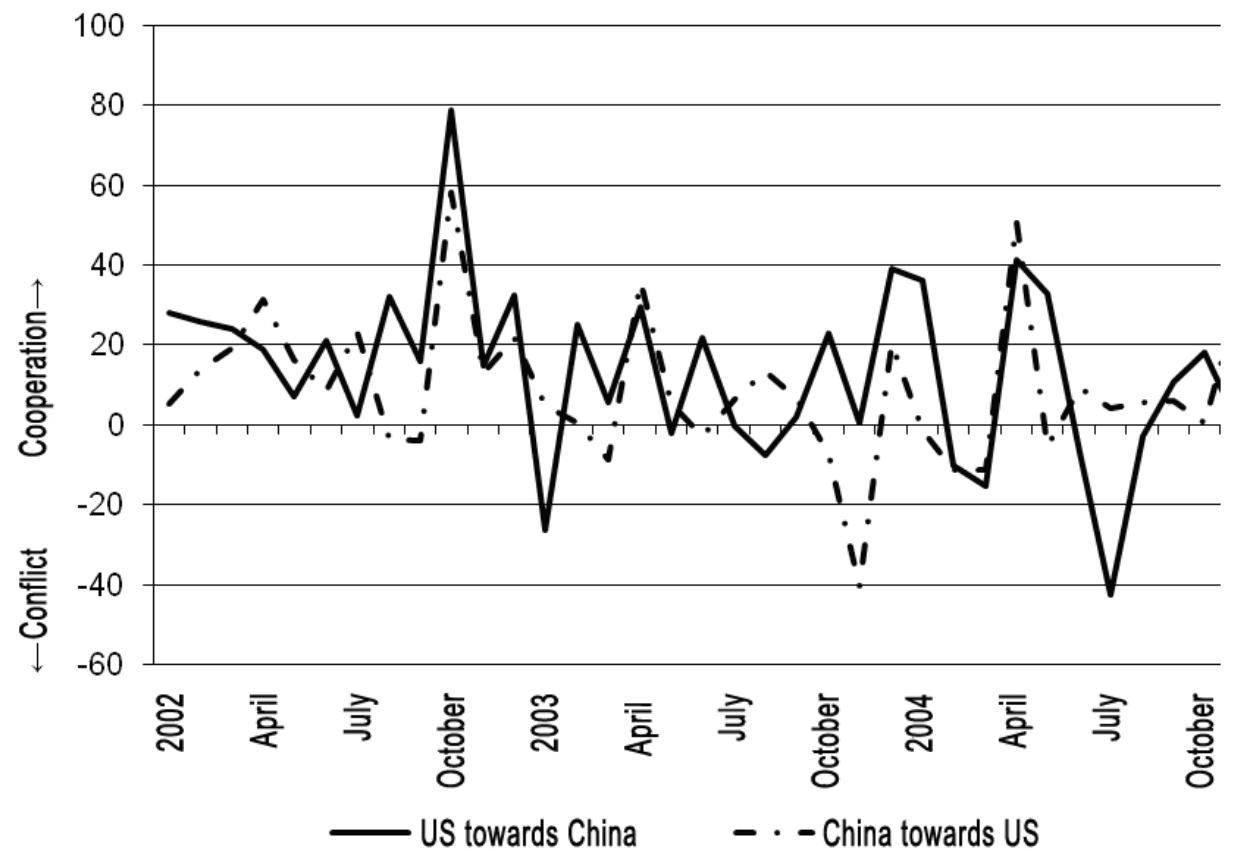

Note: Calculated as cumulative positive news scores less cumulative negative news scores. Source: King (2003).

The conflict/cooperation data are not perfect and the creation of a net cooperation variable to reflect political distance may be inappropriate, as noted previously, as some important events do not show up. Also, large events only show up as spikes in the data whereas quite often they have lasting consequences. Relying on one news source, as the data set used here does, misses news from some countries and over-reports from others. This is a difficult problem as Chinese events perhaps have better coverage than other sources, in news sources such as the China Daily, but then this data source is also far from bias free. Reuters is seen as an acceptable, more international, and bias free wire service than other news sources traditionally used such as the New York Times, which is the exclusive source for the COPDAB database. WEIS and Kansas Event Data System (KEDS) use a number of different sources and are flexible, as they allow coders to specify the data sources. There is also difficulty in isolating reporting bias for countries such as the United States as they have more international interactions and hence appear in the news the most. 


\section{Trade data}

Trade data are monthly and from the IMF's Direction of Trade Statistics. As is common practice, import data are used as there is incentive to under-report exports. The data are adjusted for seasonality and de-trended to make them into stationary series where necessary and the appropriate tests for unit roots carried out.

Two variables are used for trade and compared: nominal, absolute US dollar value trade flow from one country to another and a trade index constructed by Hirschman (1945), which is Trade $_{i j}=\frac{\left(X_{i j}+M_{i j}\right)}{\left(X_{i w}+M_{i w}\right)}$

where subscripts $i$ and $j$ on Trade indicate trade from country $i$ to $j, X_{i j}$ is exports from country $i$ to $j, M_{i j}$ is imports of country $i$ from $j$ and subscript $w$ indicates world (so $X_{i w}$ is total exports of country $i$ ). This shows the importance of country $j$ to country $i$.

Here, Hirschman's (1945) index of trade is used as it captures both types of interdependence: vulnerability (Keohane and Nye, 1977) and dependence (Hirschman, 1945). This measure is used in other studies (Reuveny and Kang, 1996 and Barbieri, 1996). Although this index is useful for capturing aspects of interdependence, a flaw in its use is discussed below. The results from using both trade variables are compared.

\section{Granger causality}

Granger causality is defined as the past values of one variable being useful in explaining the current value of another, given an information set that includes past values of both variables (Granger, 1969). A variable $X$ is said to Granger cause a variable $\Upsilon$ if lagged values of $X$ help explain values of $\Upsilon$. Granger causality is not deep causality but a method that can show there exists a relationship between variables.

The availability of rich monthly data is taken advantage of here and Granger causality is used to test the hypothesis that there is no Granger causality between trade and the net cooperation index. The direction of causality and the lag lengths are expected to be different across country pairs as many other factors affect both trade and political relations (Gasiorowski and Polachek, 1982; Reuveny and Kang, 1996).

The model is a vector autoregressive (VAR) model which looks like:

(1) $T_{t}=\sum_{i=1} \alpha_{i} T_{t-i}+\sum_{i=1} \beta_{i} C_{t-i}$
(2) $C_{t}=\sum_{i=1} \alpha_{i}^{\prime} T_{t-i}+\sum_{i=1} \beta_{i}^{\prime} C_{t-i}$ 
where $T$ is trade (the index or exports) and $C$ is net cooperation, with the subscript indicating time.

There is Granger causality if we reject the null hypothesis of $\beta$ i's $=0$ in Equation $1 \quad$ [political distance will help forecast trade in future] or $\alpha$ 'i's $=0$ in Equation 2 [trade helps forecast political distance]

The existence of a third variable which Granger causes both net cooperation and trade will give the result that net cooperation Granger causes trade or vice versa when a relationship does not exist (Granger 1980; Sims, 1980). Sims (1980) found causality is uni-directional from money to income but not vice versa in his famous 1972 paper and later showed the addition of the interest rate to the vector auto-regression effectively explains away his earlier finding. Here it is difficult to think of another variable that could be explaining both variation in the political distance between two countries and variation in their trade volumes. A third country's influence or presence could affect the results from time to time during shocks but this would be difficult to capture consistently over time and to isolate. The Japan-China relationship could be affected by the involvement of European countries, the United States, or even the multilateral landscape in general. However, it is a stretch to think of the general trend in news items between two countries to be driven by a third country. This study does not analyse the effects of external factors on the trade-political distance relationship.

Another potential problem that Sims points out is the existence of serial correlation, which can cause problems in this sort of estimation when 'some elements of optimal control enter' the model (Sims, 1972: 542). If one variable in a bivariate system is chosen optimally, the values of that variable become structural elements of the system (Sims, 1972). The only sense where that could potentially be a problem in this case is when political distance is controlled to influence trade. This is somewhat plausible but the conflict and cooperation variables include actions by many actors in each country and events out of the control of leaders, governments and authorities.

Sims (1972) points out that presence of uni-directional Granger causality can be thought of as causality but bi-directional Granger causality shows a feedback mechanism and cannot be called causality. As discussed above, it is assumed that there is a bi-directional relationship between trade and conflict and cooperation and the results below would seem to confirm this. Causality is used to refer to the direction of influence but as in the case of Granger causality analysis, it is not deep causality. The aim of this paper is to find a relationship between political distance and trade or economic interdependence and therefore instead of strict causality, finding one variable affects the other is adequate. 


\section{Why Granger causality and not cross-sectional analysis?}

It is common in the literature to find single equation cross-sectional analysis to estimate the effect of various measures of trade or interdependence on political distance. Pollins (1989a, 1989b) is generally given credit for popularising the estimation of the effect of political distance on trade. The recognition of causality running both ways between political distance and trade led to many studies estimating simultaneous equations. The problem with two stage least squares or three stage least squares estimation in analysing the relationship between political distance and trade simultaneously is that exogenous variables are needed to identify the equations. Defence expenditure has been used to identify political distance and development indicators such as education levels and highway vehicles per capita have been used to identify trade (Polachek, 1999). Using defence expenditure may be useful when analysing high-intensity conflicts with Data-sets such as MID, but in this study it is problematic for the analysis of China-Japan relations. China's defence expenditure is unclear and Japan's defence expenditure is uniquely constrained constitutionally. Also, there have not been any significant military related conflicts and nothing worthy of showing up in the MID data set. China also trades a lot more than its level of development would suggest, if such indicators were used to identify trade. For these reasons, the most common variables used to allow a simultaneous equation to work do not perform adequately for the case of Japan-China.

The results below here suggest that cross-section analysis, often only possible with annual data and depending on the country pairs, may not capture the true dynamics of international trade and political interactions, as reflected in the differing lag structures in the results.

The advantage of time series methodology is that there is greater freedom in terms of finding different lag structures among different bilateral relationships. There are some problems with this methodology that Kim and Rousseau (2005) summarise. First, the results seem to be sensitive to the number of lags included (Geweke, 1984). Secondly, as mentioned, the inclusion of a third variable can alter the results (Granger, 1980; Sims, 1980). Finally, de-trending a series (in this case the trade data) may lead to different causality conclusions (Kang, 1985).

\section{Results}

The main results of the Granger causality tests are shown in Tables 1 to 3 . An increase in the net cooperation index (a narrowing of political distance) in the tables is either an increase in cooperation or a decrease in conflict relative to the other variable. 'Japanese net cooperation' in the tables means a rise, on balance, in reports of positive over events 
that relate to country $\Upsilon$, where $\Upsilon$ is the other country in the bilateral analysis. There is no strong evidence of increased conflict causing trade to increase (which does not make sense, except in the event of some countervailing action) but there is evidence of cooperation (or a reduction in conflict) causing trade to increase.

Two tests are carried out. The first is for Granger causality: that the coefficients are jointly statistically different to zero. This is testing the joint significance of all $\beta$ 's in Equation 1 or joint significance of all $\alpha$ 's in Equation 2 (null: $\beta 1=\beta 2=\beta 3=\ldots=0$ ). The statistical significance is shown with a star next to the number of lags. The second test is whether the sum of the coefficients is statistically different to zero (null: $\beta 1+\beta 2+\beta 3+\ldots=0$ ). This is a test of whether we can confidently claim the long-run multiplier effect of one variable on the other is positive or negative, or indeed whether there is any overall statistical effect at all. This statistical significance is denoted with a star next to the sum of coefficients.

The results in Tables 1 to 3 show the sum of coefficients even if they are not statistically different to zero, as in many cases the sign is consistent over a number of lags where Granger causality was found, and it will show the general trend and is therefore useful in interpreting the results. The magnitude of the sum of coefficients is not of great value in interpreting the results as they are coefficients between de-trended and differenced trade values and an index. In Table 2 they are of less importance as they reflect the correlations between two indices.

The lag lengths differ for each country pair in the study and this is consistent with results in other studies (Reuveny and Kang, 1996). Trade contracts are in general longer term than monthly or quarterly, and the effects of large or significant events, good or bad, take time to affect trade and investment numbers. The cancellation of most contracts cannot be effected immediately and it takes time to initiate trade transactions. Similarly, an increase in trade is not followed immediately by cooperative actions or a diminution in negative actions because it takes time to report trade and FDI statistics and to respond to them. There is a lag in causality and it varies for each relationship.

The first result in Table 1 shows that an increase in the index of Chinese net cooperation towards Japan (Granger) causes Japanese exports to China to increase. This can be thought of in a number of ways. As the political climate in China towards Japan improves, China is likely to import more from Japan. Another interpretation is that as the political climate in China improves towards Japan, Japanese companies are likely to be more confident and inclined to sign contracts to supply to the Chinese market. ${ }^{6}$ 
No. 386,2010

Table 1 Trade and net cooperation, 1990-2004

\begin{tabular}{lcc}
\hline Japan-China & Lags & Sum of coefficients \\
\hline a. Japanese exports to China & $7^{* * *}$ & 13.55 \\
$=f$ (Chinese net cooperation) & $8^{* * *}$ & 8.72 \\
& $9^{* *}$ & 6.88 \\
& $10^{* * *}$ & 12.80 \\
& $11^{* *}$ & 5.87 \\
& $12^{* *}$ & 0.55 \\
b. Japanese net cooperation & $12^{*}$ & -0.024 \\
$=f($ Chinese exports to Japan) & $13^{*}$ & -0.019 \\
& $14^{*}$ & -0.023
\end{tabular}

China-United States

c. US net cooperation

$=f$ (Chinese exports to United States $)$

Lags

$=f($ Chinese net cooperation $)$

e. US net cooperation

$=f$ US exports to China)

$11^{*}$

$12 *$

$13^{* *}$

$14^{* *}$

$15^{* *}$

$16^{* *}$

$17^{* *}$

6 *

$9 *$

\section{Sum of coefficients}

$\begin{array}{cc}2^{* *} & -0.014^{* *} \\ 3^{* *} & -0.012^{*} \\ 4^{*} & -0.014^{* *} \\ 5^{* * *} & -0.017^{* * *} \\ 6^{* *} & -0.018^{* * *} \\ 7^{* *} & -0.018^{* *} \\ 8^{* *} & -0.013^{*} \\ 13^{* *} & -0.008 \\ 19 * * & -0.004\end{array}$




\begin{tabular}{lcc}
\hline Japan-United States & Lags & Sum of coefficients \\
\hline f. Japanese net cooperation & $3^{*}$ & 0.005 \\
$=f$ (Japanese exports to United States) & $4^{*}$ & -0.001 \\
& $10^{*}$ & -0.023 \\
& $11^{*}$ & -0.026 \\
& $12^{* *}$ & -0.020 \\
& $13^{*}$ & -0.015 \\
g. US exports to Japan & $14^{* *}$ & $3.60^{*}$ \\
$=f($ Japanese net cooperation) & $15^{* *}$ & $3.61^{*}$ \\
& $16^{* *}$ & 2.37 \\
& $17^{* *}$ & 2.17 \\
& $18^{* *}$ & 1.81 \\
h. US exports to Japan & $3^{* *}$ & 2.31 \\
$=f$ (US net cooperation) & $4^{*}$ & 2.54 \\
$5^{*}$ & 2.89 \\
& $6^{*}$ & $3.47^{*}$ \\
\hline
\end{tabular}
Notes: ${ }^{*}=10$ per cent level of significance, ${ }^{* *}=5$ per cent level of significance and $* * *=1$ per cent level of significance. Statistical significance on the lag number signifies joint statistical significance of all the lags from one lag up to that number (presence of Granger causality) and significance on the sum of coefficients is a test whether the sum of all the lags is significant.

The second Japan-China result (Table $\mathrm{lb}$ ) is that increasing Chinese exports to Japan help explain a fall in the index of cooperation from Japan towards China. Increased Japanese imports of Chinese goods after 12 months can be seen to worsen the climate in Japan towards China. This is consistent with what the media often refers to as the 'China fear' in Japan of industry hollowing out and jobs being lost to China as well as Japan's fear of losing its economic dominance in the region. Table 3 (p. 181) below shows stronger evidence of this result, which supports realist hypotheses of trade sometimes increasing political distance.

The United States-China results show strong evidence that trade flows reduce net cooperation (widen political distance) in the United States towards China. The sum of the coefficients is mostly statistically significant and both an increase in Chinese exports to the United States and United States exports to China cause the United States' stance towards China to worsen.

Finally for Table 1, that Japanese exports to the United States help explain a reduction in the Japanese net cooperation index towards the United States is unexpected (Table lf). The sum of the lag coefficients is very small and closer inspection of the data shows a mix of positive and negative coefficients for different lags. ${ }^{7}$ The other results (Table $1 \mathrm{~g}$ and $\mathrm{h}$ ) show increases in the index of cooperation in both directions, which helps explain increased United States trade to Japan. 
In Table lb Chinese exports to Japan were explaining falls in Japanese net cooperation (or increasing political distance) towards China; in Table 2a an increase in China's dependence on Japan helps explain the opposite effect, a positive movement on the net cooperation scale and the countries becoming politically closer. The results are not inconsistent, as the dependence index used here captures the increasing importance of Japan for China, reflected in its rising dependence and vulnerability in relation to Japan. This nuanced story is only picked up with the use of both the nominal export variable and the trade index of dependence.

The results of increased Japanese dependence on China are mixed (Table 2b). Although one could interpret the change in sign after 13 months, from a negative to a positive effect on Japan's stance towards China, as the change over time of the effect of Japan's integration with China on the country as a whole, the sum of the coefficients is not statistically significant and the results cannot be interpreted as confidently as other results. All that can be said is that Japanese dependence on China Granger causes a change in political distance. 
Asia Pacific Economic Papers

Table 2 Interdependence and net cooperation, 1990-2004

\begin{tabular}{|c|c|c|}
\hline Japan-China & Lags & Sum of coefficients \\
\hline $\begin{array}{l}\text { a. Japanese net cooperation } \\
\qquad=f(\text { Chinese dependence on Japan })\end{array}$ & $\begin{array}{l}5^{* *} \\
6^{* *} \\
7^{* *} \\
8^{* * *} \\
9^{* *} \\
10^{* *} \\
11^{* *} \\
12^{* *} \\
13^{* *}\end{array}$ & $\begin{array}{l}810 \\
1264^{* *} \\
1516^{* *} \\
2244^{* * *} \\
2323^{* * *} \\
1983^{* *} \\
2719^{* *} \\
2025^{*} \\
2735^{*}\end{array}$ \\
\hline $\begin{array}{l}\text { b. Japanese net cooperation } \\
\qquad=f(\text { Japanese dependence on China })\end{array}$ & $\begin{array}{l}12^{*} \\
13^{*} \\
14^{*} \\
15^{*}\end{array}$ & $\begin{array}{l}-752 \\
-180 \\
286 \\
622\end{array}$ \\
\hline $\begin{array}{l}\text { c. Japanese dependence on China } \\
\quad=f(\text { Japanese net cooperation })\end{array}$ & $2^{*}$ & -0.00012 \\
\hline Japan-US & Lags & Sum of coefficients \\
\hline $\begin{array}{l}\text { d. Japanese net cooperation } \\
\quad=f(\text { Japanese dependence on United States })\end{array}$ & $\begin{array}{l}6^{* *} \\
7 * * \\
8 * * \\
9 * *\end{array}$ & $\begin{array}{l}5313^{* * *} \\
6173^{* * *} \\
7790 * * * \\
8320 * * *\end{array}$ \\
\hline $\begin{array}{l}\text { e. US net cooperation } \\
\quad=f(\text { Japanese dependence on United States })\end{array}$ & $\begin{array}{l}6^{* *} \\
18^{* *} \\
19^{* *} \\
20^{* *} \\
21^{* *} \\
22^{* * *}\end{array}$ & $\begin{array}{l}2918 \\
15380^{* * *} \\
14835^{* *} \\
18568^{* * *} \\
24198^{* * *} \\
28415^{* * *}\end{array}$ \\
\hline $\begin{array}{l}\text { f. US net cooperation } \\
\qquad=f(\text { US dependence on Japan })\end{array}$ & $\begin{array}{l}2^{*} \\
3^{* * *} \\
4^{* * *} \\
5^{*} \\
6^{*}\end{array}$ & $\begin{array}{l}418 * * \\
581 * * * \\
602 * * * \\
542 * * * \\
517 * *\end{array}$ \\
\hline
\end{tabular}

Notes: ${ }^{*}=10$ per cent level of significance, ${ }^{*} * 5$ per cent level of significance and $* * *=1$ per cent level of significance. Statistical significance on the lag number signifies joint statistical significance of all the lags from one lag up to that number (presence of Granger causality) and significance on the sum of coefficients is a test whether the sum of all the lags is significant.

The Granger causality estimations carried out on interdependence and cooperation, using the trade index, do not include the United States-China case because the highly unbalanced trade relationship distorts the trade index. ${ }^{8}$ 
The results showing a positive relationship between net cooperation and dependence for Japan and the United States are strong (Table 2d, e and f). There is uni-directional causality from dependence to political distance showing that mutual interdependence fosters cooperation and narrows political distance - the classic liberal hypothesis.

As the causality, direction of causality and lag lengths vary by country pair, it is reasonable to assume that even within a country pair the dynamics and interactions change over time. To take account of, and to test for this, two additional steps are taken. First, to test whether the longer term relationships in Tables 1 and 2 are consistent over time, or whether the pattern (or even nature) of the interactions changes over time, the fifteen-year period was split roughly into half. In order to keep the number of observations high, the eight and seven-year split represents the only sub-periods analysed. Table 3 shows that the results are significantly different between the two time sub-periods.

Table 3 reveals more evidence of the existence of a trade-cooperation nexus, which is perhaps hidden in the longer series. It is interesting to note there is a stronger link between trade and political distance in the period 1998-2004 while there is a stronger dependence-political distance link in the earlier period 1990-1997. For example, there is no evidence found of Granger causality between trade dependence and political distance in the period 1998-2004. The result from Table la, that Chinese net cooperation towards Japan Granger causes Japanese exports to China is present in both periods in Table 3a but with ambiguity of the sign of the effect. Analysis of the longer time period may better capture the long-term underlying direction of the effect, if there is one at all.

The most significant result is that an increase in Japanese net cooperation towards China appears to lift Japanese exports to China (Table 3c). This is the equivalent to saying an increase in conflict from Japan towards China Granger causes a reduction in Japanese exports to China. Again, the sum of coefficients is not significantly different to zero but is consistently positive and well above the magnitude of the individual lag coefficients, which range from 1.8 to 13 in this case.

The other result from Table $\mathrm{lb}$, that Chinese exports to Japan are causing the measure of conflict from Japan to China to rise, is confirmed in Table $3 \mathrm{~b}$ but with evidence only found in the latter period. It is reasonable to expect that the 'China fear' that is a product of China's rise is more pronounced in the second period analysed as China became a much bigger player internationally and in trade with Japan, and the direct threat to Japan's regional dominance became more apparent.

The main Japan-China result from Table 2a, that growing Chinese dependence on Japan is causing Japanese net cooperation towards China to rise, is also found in Table $3 \mathrm{i}$ but is only apparent in the earlier period.

The nuanced story from Table 1 can be extended to: Japanese net cooperation 
Asia Pacific Economic Papers

towards China is positively affected in the earlier period by Japan's growing importance to China and negatively affected in the latter period by the growing exports of China to Japan, as China's dominance grows and becomes more visible. 
No. 386,2010

Table 3 Japan-China trade/interdependence and net cooperation by sub periods, 1990-1997 and 1998-2004

1997-1997

$1998-2004$

Trade and Net Cooperation

Lags Sum coeffs

Lags

Sum coeffs

a. Japanese exports to China

$=f$ (Chinese net cooperation $)$

$\begin{array}{cc}7^{* *} & 6.30 \\ 8^{* *} & -1.35 \\ 9^{* *} & -0.73 \\ 10^{* * *} & 6.48 \\ 16^{*} & -12.0\end{array}$

$2^{*}$

$-0.79$

$3 * \quad-0.54$

$7 *$

22.12

$16^{*}$

$-12.0$

$\begin{array}{cc}12 \text { * } & 8.85 \\ 13 * & 7.44\end{array}$

b. Japanese net cooperation

$=f$ (Chinese exports to Japan $)$

c. Japanese exports to China

$=f$ (Japanese net cooperation)

d. Japanese net cooperation

$=f($ Japanese exports to China $)$

e. Chinese net cooperation

22 **

0.317

0.220

$=f($ Japanese exports to China $)$

$23^{*}$

$24^{*}$

0.358

12 *

$-0.07 * * *$

$13 *$

$-0.06^{* *}$

$14^{* *}$

$-0.08 * * *$

$15^{* *}$

$-0.08 * * *$

$16^{*}$

$-0.07 * *$

$12 * * *$

24.7

$13^{* *}$

25.4

$14^{* *}$

20.5

$15^{* *}$

22.4

$16^{*}$

22.5

$13 *$

$-0.16^{*}$

2 *

0.003

$4^{*} \quad-0.006$

$5^{* *} \quad 0.003$

$6^{*}$

$-0.002$

f. Chinese exports to Japan

11 *

$26.7^{* * *}$

$=f$ (Japanese net cooperation $)$

g. Chinese net cooperation

$=f$ Chinese exports to Japan $)$

$\begin{array}{cc}6^{* *} & 0.030 \\ 7 * * & 0.027 \\ 8^{*} & 0.034 \\ 12^{*} & 0.111^{* *} \\ 13^{*} & 0.126^{* *} \\ 15^{*} & 0.181^{* * *}\end{array}$

h. Chinese exports to Japan

$=f$ (Chinese net cooperation $)$ 


\begin{tabular}{|c|c|c|c|c|}
\hline Dependence and Net Cooperation & Lags & Sum coeffs & Lags & Sum coeffs \\
\hline $\begin{array}{l}\text { i. Japanese net cooperation } \\
\quad=f(\text { Chinese dependence on Japan })\end{array}$ & $\begin{array}{c}2^{*} \\
3^{* *} \\
4^{*} \\
5^{* *} \\
6^{* * *} \\
7^{* *} \\
8^{* *} \\
9^{* *} \\
10^{*} \\
11^{*} \\
12^{*}\end{array}$ & $\begin{array}{c}-374 \\
-866 \\
-466 \\
54 \\
985 \\
1069 \\
1719 \\
1696 \\
1733 \\
2279 \\
1672\end{array}$ & & - \\
\hline $\begin{array}{r}\text { j. Chinese dependence on Japan } \\
=f(\text { Chinese net cooperation })\end{array}$ & $3 * *$ & -0.0002 & & - \\
\hline $\begin{array}{l}\text { k. Chinese net cooperation } \\
\quad=f(\text { Chinese dependence on Japan })\end{array}$ & $\begin{array}{c}20^{* *} \\
21^{* *} \\
22^{* * *} \\
23^{* * *} \\
24^{* *}\end{array}$ & $\begin{array}{c}3942^{*} \\
4140 \\
5678^{*} \\
6397^{*} \\
6198\end{array}$ & & - \\
\hline $\begin{array}{l}\text { 1. Chinese net cooperation } \\
=f(\text { Japanese dependence on China })\end{array}$ & $\begin{array}{c}8^{*} \\
20^{* *} \\
21^{*} \\
22^{*} \\
23^{*}\end{array}$ & $\begin{array}{c}1991^{*} \\
4851^{*} \\
3985 \\
4201 \\
3738\end{array}$ & & - \\
\hline
\end{tabular}

Notes: ${ }^{*}=10$ per cent level of significance, ${ }^{* *}=5$ per cent level of significance and $* * *=1$ per cent level of significance. Statistical significance on the lag number signifies joint statistical significance of all the lags from one lag up to that number (presence of Granger causality) and significance on the sum of coefficients is a test whether the sum of all the lags is significant.

\section{Net cooperation as the appropriate measure of political distance}

The net cooperation variable used in this study follows the seminal papers of Polachek (1980) and Pollins (1989a). Other studies use only conflict and it could be argued a ratio of cooperation to conflict could pick up different dynamics between conflict and cooperation and not restrict it to one functional form. It is reasonable to assume that it is not conflict (negative news) alone, or cooperation (positive news) that drives trade, but the net effect of both. To subtract conflict from cooperation imposes the assumption that they are additive and that the reporting of certain events cancels out the reporting of others. One approach might be to test the robustness of the results with the ratio of cooperation to conflict. This, however, is difficult as there are frequent zero values in the 
news events, where no positive or negative news item was reported in that month for the bilateral relationship. Also, despite the fact that this would test another shape of the relationship between cooperation and conflict, and its relationship with trade, it seems more appropriate to think of cooperation and conflict as additive, as positive and negative utility towards another country.

The Granger causality tests from Tables 1 and 2 were repeated but with conflict and cooperation separately. While some results confirm the results in Tables 1 and 2, and even some in Table 3, a majority of results were not consistent and did not make sense with what is observed in reality. These inconclusive results suggest that in analysing the relationship between political distance and trade, it does not make sense to look at only the positives or only the negatives of political distance, in isolation from each other.

\section{Implications}

The three relationships covered here include neighbours (Japan and China), rivals (the United States and China; China and Japan), allies (the United States and Japan), democracies and a one-party state. No generalisations are made about the characteristics of the countries and their effect on the trade-political distance relationship as is done elsewhere - there is often a lack of sensible bounds on conclusions and results are generalised across time and countries (Mansfield and Pollins, 2001).

The results in this study are not completely consistent with Reuveny and Kang (1996). Reuveny and Kang find that causality tends to be reciprocal, whereas in this study causality seems to be uni-directional when only applying the linear results that they use. The conclusion Reuveny and Kang draw that the pattern of the interaction between politics and economics differs for each country relationship is, however, supported by this study.

There is evidence in the present study that supports both the liberal and realist schools. The findings are consistent with the theories described previously of low-intensity conflict in a relationship underpinned by strong economics, of enduring rivalries and neighbourly disputes that are mitigated by trade (Robst et al., 2006). The structure of Japan-China relations at this point makes them relatively low-intensity in the generation of conflict.

\section{The Japan-China relationship}

This analysis leads to a number of important conclusions. The economic relationship underpins the relationship between China and Japan, and the results here show that the economic relationship constrains the political relationship. This result is in direct contrast to a study by Hughes and $\mathrm{He}$ (2006), which concluded that the pacifying effects of trade (as posited by liberal theories) are dominated by nationalism in the case of Japan-China 
Asia Pacific Economic Papers

relations.

Yasukuni Shrine is the most talked about issue and is most symbolic of the difficulties between Japan and its largest neighbours, China and South Korea. In a sign of the recognition of the importance of the relationship, Prime Minster Abe did not visit the shrine while he was leader and in the contest for leadership after Abe, Fukuda, who eventually won the contest, gave a clear message that in order to mend relations with Asian neighbours, a Yasukuni Shrine visit would not take place. ${ }^{9}$ Recognition of the implications of shrine visits is now clear and even if future leaders do seek to increase political tensions for domestic political reasons, it would appear these actions would be taken in a manner so as to minimise the damage to Japan-China relations. ${ }^{10}$ As the results here suggest, politics or variations in political distance do appear to have an effect on the bilateral trade relationship and trade affects political distance (See Table $1 \mathrm{a}$ and $\mathrm{lb}$; Table 3a, b and c).

There is some evidence of increased low-intensity conflict from Japan towards China as Chinese trade to Japan increases, but this can be explained by the underlying economic relationship's being strong enough that the Japanese leaders and some actors in the economy can cause low-intensity conflict for domestic political reasons. This is consistent with the media reports of 'China fear' and with the findings of Robst et al. (2006) and Gartzke (1998). Tensions may rise significantly if trade started to become unbalanced as in the United States-China case. The Japan-China trade relationship is currently relatively balanced and a growing Japanese deficit with China would have to be managed carefully to dampen tensions and rising nationalism between the two countries.

Thus, these low-intensity conflicts between Japan and China would seem unlikely to escalate as the countries become more integrated economically, unless trade becomes largely lopsided. Increased trade, and also investment, have meant that both forms of interdependence, vulnerability and dependence, have grown. The increased vulnerability of one country towards the other and the unresolved historical issues complicate and fuel domestic sentiments in some segments of both countries and from time to time it would appear that both governments play these up for domestic political gain.

Hughes and $\mathrm{He}$ (2006) state that the economic interdependence between Japan and China is a weaker factor than nationalism and that although increased economic interdependence has increased the cost of conflict, the risk of escalation has increased. The results in this current study would suggest otherwise.

The results of this study suggest that Japanese exports to China are increasingly affected by Japanese political distance from China (Tables $1 \mathrm{a}, 3 \mathrm{a}$ and $3 \mathrm{c}$ ). A rise in negative Chinese sentiments towards Japan and increasingly a rise in Japan's negative sentiments towards China adversely affect Japanese exports. ${ }^{11}$ Japan's politicians are increasingly constrained in actions that might affect China and Chinese sentiments. 
The economic relationship is now being driven by market forces and not significantly directed by policy intervention (Drysdale, 2007) as the highly complementary industrial structures and proximity of both countries drive the growth in trade. And the politics affect the economic relationship in some areas more than others, as some Japanese companies feel they are global brands that can de-link themselves from their country of origin (Armstrong, 2007). However, the Chinese economy, especially after WTO accession, is much more of a level playing field for companies from Japan, the United States and Europe and Japan's advantage of being in China early is diminishing rapidly. The evidence of Japanese net cooperation affecting Japanese exports to China after 1998 shows that it is important for Japanese actors in the Chinese economy not to have to carry Japanese political baggage in competing with others in that market (Armstrong, 2007). The interaction between politics and trade would appear to be more pronounced in the later period analysed. Since this period saw rapid economic growth it can be concluded that it caused an improvement in political distance.

As the bilateral economic relationship between the two countries becomes even more important than it already is, its effect on the politics between the two countries is likely to grow. The period since late 2006 has seen political tensions ease with visits by both leaders to the other country and efforts from both governments to resolve some important issues. Significant examples include the joint experts commission set up to agree on disputed interpretations of history and an agreement to pursue jointly, and eventually commit to, a bilateral trade agreement (free trade agreement or a broader economic partnership agreement).

It is possible that when significant negative events are reported and political distance is seen to be widening, there are some actors in each country that would try and cancel these out with positive events. For example, the Chinese and Japanese governments have created second-track dialogue forums (the Beijing Tokyo Forum, for example) and increased grass roots exchanges. The period of rising tensions from 2001 also saw positive cooperation events increase from China's WTO entry. The net effect was that the news and closer economic ties from China's WTO entry cancelled out the negative political news.

\section{Further work}

Economic relationships between countries involve a lot more than just trade in goods. An obvious next step would be to undertake a similar systematic study that included services trade. Also of particular importance in the China-Japan relationship is foreign direct investment (FDI) as it is a big part of the relationship and is likely to be equally responsive 
to the political climate, if not more so.

Another extension the analysis is to take account of multilateral, or third party, effects of political distance and trade. It is not difficult to see why the influence of the United States could have an effect on Japan-China trade, or that as the political distance between Japan and China increases, trade through Hong Kong or other countries will increase.

\section{Conclusion}

The purpose of this study was to test whether there is any relationship between trade and political distance, and the direction of its causality in the Japan-China relationship. The interactions of both countries with the United States were analysed by way of comparison. The study uses the latest events data available (up to 2004) with high frequency (monthly) data.

The main results are that a narrowing of political distance helps explain an increase in Japanese exports to China; in the 1990-1997 period; growth in Japan's importance to China increases Japanese cooperation towards China; and in the 1998-2004 period an increase in Japanese cooperation towards China helps explain an increase in Japanese exports to China. Chinese imports of Japanese products do not appear to be independent of how well the countries are getting along.

Growing Chinese exports to Japan and the United States are causing a rise in the measure of negative sentiment towards China, but the growth of Japanese trade to China dampens this effect. The large imbalance in the trade relationship between China and the United States is causing tensions to rise in the United States from increased trade in both directions.

The stable and rapidly growing economic relationship, of which trade flows are a big part, constrain political behaviour between China and Japan. The rising interdependence between the nations and concomitant opportunity cost of serious conflict has led to an easing of political tensions and even some narrowing of political distance. The structure of the political relationship appears likely, from this analysis, to be increasingly affected by the economic relationship. 


\section{Notes}

$1 \quad$ See Mansfield and Pollins (2003) for a review of the literature.

2 Here the use of 'conflict' and 'cooperation' is in terms of political conflict and political cooperation. Trade tensions (such as trade disputes) are part of political conflict and act to widen political distance. Conflict and cooperation widen and narrow economic distance by widening and narrowing political distance.

3 For a discussion of this see Mansfield and Pollins (2001).

4 For a discussion of the literature, including empirical studies, see Polachek and Seiglie (2006).

5 Available at http://gking.harvard.edu/events/

6 It could be argued that the political climate in China towards Japan will be affected by the political climate in Japan towards China.

$7 \quad$ The coefficients of each lag are not reported here as they are in some other papers (Sims, 1972) because the sheer amount of data and the relationships for which they may be interesting (JapanUnited States) are not the main aim of this paper.

8 Hirschman's index of trade dependence does not perform well for highly unbalanced trade or rapidly growing imbalances in trade. The direction of trade is irrelevant in the index so it does not treat China's growing surplus (the United States' growing deficit) as trade increasing in one direction. As the theories and literature tell us, it is the asymmetry in trade, or the growing imbalance, that is the driver of conflict and so the index would only appear to perform well for trade that is relatively even.

9 There has been increasing talk of either removing the souls of the 14 Class A war criminals from Yasukuni, or failing that technically, creating another memorial for Japan's war dead that does not include the war criminals.

10 This could also be the case with other economically important yet politically sensitive relations such as between Japan and South Korea.

11 Here and at other times the measured events which cover all news items are used as a proxy for sentiment. 


\section{References}

Armstrong, S. P., 2007. 'Commercial Self-interest a Politic Course', The Australian Financial Review, 11 April 2007, p. 63.

Baek, E. and Brock, W., 1992. 'A general test for granger causality: Bivariate model', Technical Report, Iowa State University and University of Wisconsin, Madison.

Barbieri, K., 1996. 'Economics Interdependence: A path to peace or a source of conflict?', Journal of Peace Research, 33: 29-50.

—. and G. Schneider, 1999. 'Globalization and peace: assessing new directions in the study of trade and conflict', Journal of Peace Research, 36:387-404.

Blainey, G., 1973. Causes of War, The Free Press, New York.

de Secondat, Charles, Baron de Montesquieu, 1989. 'Montesquieu: Spirit of the Laws', in Anne M. Cohler, Basia Carolyn Miller, and Harold Samuel Stone (eds.) Cambridge Texts in the History of Political Thought, Cambridge University Press, Cambridge.

Diks, C. and V. Panchenko, 2006. 'A new statistic and practical guidelines for nonparametric Granger causality testing', Journal of Economic Dynamics and Control, 30 (9-10), 1647-1669.

Drysdale, P., 2007. 'Japan and China: Towards a New Era in Asia-Pacific Cooperation?', Speech at International House of Japan, Tokyo, 22 May.

Fujihara, R. and M. Mougoue, 1997. 'An examination of linear and nonlinear causal relationships between price variability and volume in petroleum futures markets', The Journal of Futures Markets, 17(4): 385-416.

Gartzke, E., 1998. 'Kant We All Just Get Along? Motive, Opportunity, and the Origins of the Democratic Peace', American Journal of Political Science, 42: 1-27.

— Q. Li and C. Boehmer, 2001. 'Investing in the peace: Economic Interdependence and international conflict', International organization, 55: 391-438.

Gasiorowski, M. and S. Polachek, 1982. 'Conflict and interdependence: East West trade and linkages in the era of détente', Journal of Conflict Resolution, 26: 709-730.

Geweke, J., 1984. 'Inference and Causality in Economic Time Series Models', in Z. Griliches and M. Intriligator (eds), Handbook of Econometrics, Volume 2. New York: North-Holland (1101-1144).

Gilpin, R., 1981. War and Change in World Politics. Princeton University Press, Princeton NJ.

Goldstein, J. S., 1992. 'A conflict-cooperation scale for WEIS event data', Journal of Conflict Resolution, 36:369-385.

Granger, C. W. J., 1980. 'Testing for Causality: A Personal Viewpoint', Journal of Economic Dynamics and Control, 2(4): 329-352.

Grieco, J. (1988) 'Anarchy and the Limits of Cooperation. A Realist Critique of the Newest Liberal Institutionalism', International Organization, 42: 485-507.9

Hiemstra, C. and Jones, J. D., 1994. 'Testing for linear and nonlinear Granger Causality in the stock price-volume relation', Journal of Finance, 49(5): 1639-1664.

Hirschman, A., [(1945)1980]. National Power and the Struggle of Foreign Trade, University of California Press, Berkeley.

Kang, H., 1985. 'The Effects of Detrending in Granger Causality Tests', Journal of Business and Economic Statistics, o 3(4): 344-349.

Kant, I., 1795. 'Eternal Peace and Other International Essays', translated by W. Hastie, The World Peace Foundation, Boston.

Keohane, R. and J. Nye, 1977. Power and Interdependence, Little, Brown, Boston Massachusetts.

Kim, H. and D. Rousseau, 2005. 'The Classical Liberals Were Half Right (or HalfWrong): New Tests of the Liberal Peace, 1960-88', Journal of Peace Research, 42/5 (September), 523-543. 
King, G and W. Lowe, 2003. 'An Automated Information Extraction Tool For International Conflict Data with Performance as Good as Human Coders: A Rare Events Evaluation Design; International Organization, 57(3) (July): 617-642.

King, Gary, 2003. '10 Million International Dyadic Events', hdl:1902.1/FYXLAWZRIA UNF:3: um06qkr/ltAwpS4roUqAiw== Murray Research Archive [Distributor] http://gking.harvard. edu/homepage.html

Levy, J., 1989. 'The Causes of War: A Review of Theories and Evidence', in P. Tetlock (ed.) Behavior Society and Nuclear War, Oxford University Press, New York.

Mansfield, E. and B. Pollins, 2003. 'Interdependence and Conflict: An Introduction', in E. Mansfield and B. Pollins (eds.) Economic Interdependence and International Conflict: New Perspectives on an Enduring Debate, University of Michigan Press, Michigan.

Mearsheimer, J., 1990. 'Back to the Future: Instability in Europe After the Cold War', International Security, 15 (1):5-56.

O'Loughlin, J., 1993. 'The Political Geography of U.S. and Japanese Trade in the Pacific Rim 196688', Transactions, Institute of British Geographers NS 19, 438-59.

Pevehouse, J., 2003. 'Trade and Conflict: Does Measurement Make a Difference?', in E. Mansfield and B. Pollins (eds.) Economic Interdependence and International Conflict: New Perspectives on an Enduring Debate, University of Michigan Press, Michigan.

Polachek, S. W., 1978. 'Dyadic dispute: an economic perspective', Papers of the Peace Science Society, 28:67-80.

- 1980. 'Conflict and trade', Journal of Conflict Resolution, 24: 55-78.

1997. 'Why democracies cooperate more and fight less: the relationship between international trade and cooperation', Review of International Economics, 5:295-309.

_ 1997 . 'Why Democracies Cooperate More and Fight Less: The Relationship Between International Trade and Cooperation', Review of International Economics, 5: 295-309.

—. and C. Seiglie, 2006. 'Trade, Peace and Democracy: An Analysis of Dyadic Dispute', IZA Discussion Papers 2170, Institute for the Study of Labor (IZA).

Pollins, B., 1989a. 'Conflict, Cooperation, and Commerce', American Journal of Political Science, 33:737-61.

— 1989b. 'Does Trade Still Follow the Flag?', American Political Science Review, 83:465-80.

Reuveny, R. and H. Kang, 1996. 'International Trade, Political Conflict/Cooperation, and Granger Causality', American Journal of Political Science, 40: 943-970.

_ 1998 . 'Bilateral trade and political conflict/cooperation: do goods matter?', Journal of Peace Research, 35:581-602.

_ 2 2003. 'A simultaneous-equations model of trade, conflict, and cooperation', Review of International Economics, 11:279-95.

Robst, J, S. Polachek and Y. Chang (2006) 'Geographic Proximity, Trade and International Conflict/ Cooperation', IZA Discussion Papers 1988, Institute for the Study of Labor (IZA).

Sims, C. A., 1972. 'Money, Income, and Causality', American Economic Review, 62 (4): 540-552.

— 1980. 'Comparison of Interwar and Postwar Cycles: Monetarism Reconsidered', NBER Working Paper, No. 430.

Stinnett, D. and P. Diehl, 2001. 'The Path(s) To Rivalry: Behavioral and Structural Explanations of Rivalry Development', Journal of Politics 63 (3) (August): 717-740.

Tinbergen, J., 1962. Shaping the World Economy: Suggestions for an International Economic Policy, The Twentieth Century Fund, New York

Vasquez, J., 1995. 'Why Do Neighbours Fight? Proximity, Interaction, or Territoriality' Journal of Peace Research 32 (3): 277-293.

Waltz, K., 1979. Theory of International Politics, McGraw-Hill, New York.

Wright, Q., 1942. A Study of War, University of Chicago Press, Chicago. 


\section{Appendix}

\section{Appendix A Conflict data for Japan-China}

\section{Table 4 Conflict data from China towards Japan}

\begin{tabular}{|c|c|c|c|c|c|c|c|c|c|c|c|c|c|}
\hline \multicolumn{13}{|c|}{ Month $\rightarrow$} & Total \\
\hline 1990 & 0 & 5 & 0 & 0 & 10.4 & 2.2 & 5.1 & 0 & 0 & 9.9 & 0 & 0 & 32.6 \\
\hline 1991 & 4 & 0.1 & 0 & 0 & 0 & 9.8 & 0 & 0.1 & 0 & 0 & 0 & 0 & 14 \\
\hline 1992 & 0 & 0 & 9.2 & 5 & 0 & 0 & 0.1 & 0 & 0.1 & 0 & 0 & 0 & 14.4 \\
\hline 1993 & 0 & 11.1 & 9.3 & 0 & 0 & 0 & 0.1 & 0 & 0 & 0 & 0 & 0 & 20.5 \\
\hline 1994 & 0 & 0 & 0 & 0 & 0 & 0 & 0 & 0 & 20.5 & 7.1 & 0 & 0 & 27.6 \\
\hline 1995 & 8.8 & 0 & 17.7 & 4.9 & 0 & 2.2 & 0 & 4.9 & 8.7 & 0 & 9.3 & 0 & 56.5 \\
\hline 1996 & 4.9 & 0 & 0 & 6 & 0 & 2.2 & 12 & 12.3 & 36.2 & 7.4 & 0 & 6.7 & 87.7 \\
\hline 1997 & 0 & 4 & 0 & 2.3 & 9.1 & 12 & 0.1 & 9.3 & 8.5 & 0 & 0 & 0 & 45.3 \\
\hline 1998 & 0 & 0 & 0 & 0.1 & 5.2 & 17.2 & 0 & 5 & 2.3 & 8 & 10.3 & 0 & 48.1 \\
\hline 1999 & 0 & 0 & 0 & 0.1 & 2.3 & 0 & 3 & 0 & 0.1 & 0 & 4.9 & 0 & 10.4 \\
\hline 2000 & 5 & 3 & 4 & 6.2 & 2.2 & 0 & 0 & 0 & 2.2 & 0 & 0 & 6.4 & 29 \\
\hline 2001 & 0 & 9 & 3 & 13 & 21.2 & 7.6 & 9.4 & 0.2 & 4.9 & 0 & 4 & 8.2 & 80.5 \\
\hline 2002 & 9.9 & 4.9 & 0 & 19.9 & 12.4 & 0 & 0 & 4.9 & 4 & 0 & 7 & 0 & 63 \\
\hline 2003 & 11.2 & 0 & 0 & 4.9 & 0 & 0 & 0 & 14.2 & 8.8 & 4.9 & 0 & 0.1 & 44.1 \\
\hline 2004 & 0 & 0 & 14.2 & 2.2 & 0 & 4.4 & 4.6 & 3 & 0 & 8 & 2.2 & 10.6 & 49.2 \\
\hline
\end{tabular}

Notes: Shaded months indicate a Yasukuni shrine visit by Prime Minister Koizumi. The first visit, in 2001, was preceded by an announcement in May that year which got all the press. The visit itself was not reported so prominently and did not cause as much negative news as in May perhaps because Koizumi gave in to Chinese pressure in August and did not visit the shrine on the highly significant anniversary of the end of the war, 15 August, but instead on 13 August. The visit on 2004 happened on New Year's day when it is tradition for Japanese to visit shrines and temples and this could be the reason it was not reported as a negative event. Indeed, there is much less news coverage of this visit than the others.

The largest conflict month is September 1996 with a score of 36.2. This is when Japan, China and Taiwan all claimed ownership of uninhibited islands in the East China Sea, thought to have oil. From the International Herald Tribune: 'Japan's persistent moves to assert sovereignty over the islands, known as the Senkakus in Japanese and the Diaoyus in Chinese, have whipped up a storm of nationalist fervour by angering Chinese in China, Taiwan, Hong Kong and Macau - despite their political differences. But analysts say that the main reason Japan and China will continue to press their claims, even at the risk of confrontation, is that both countries want access to energy resources close to their shores.' (17 September 1996). 
No. 386,2010

Table 5 Conflict data from Japan towards China

\begin{tabular}{lccccccccccccc}
\hline $\begin{array}{l}\text { Month } \rightarrow \\
\text { Year } \downarrow\end{array}$ & Jan & Feb & Mar & April & May & June & July & Aug & Sept & Oct & Nov & Dec & Total \\
\hline 1990 & 0.1 & 0 & 3 & 0 & 0.1 & 0.1 & 8.8 & 0 & 0 & 14 & 0 & 0 & 26.1 \\
1991 & 0.2 & 0 & 0 & 0 & 2.4 & 4.9 & 0 & 0 & 0 & 0 & 0 & 0 & 7.5 \\
1992 & 9.8 & 2.4 & 0 & 4.4 & 4.4 & 2.4 & 4.4 & 14.4 & 0 & 0 & 0 & 0 & 42.2 \\
1993 & 12.2 & 0 & 0 & 0 & 0 & 4.9 & 0 & 0 & 0 & 0 & 0.1 & 0 & 17.2 \\
1994 & 0 & 0 & 0.1 & 0 & 4.9 & 0.1 & 2.2 & 4.9 & 4.1 & 15.5 & 0 & 0 & 31.8 \\
1995 & 0 & 0 & 0 & 4 & 4.6 & 2.3 & 4.2 & 22.4 & 0.1 & 0 & 0 & 6.6 & 44.2 \\
1996 & 0 & 5.9 & 18.8 & 0 & 2.3 & 6.3 & 4.6 & 0.1 & 8.3 & 1 & 0 & 4.4 & 51.7 \\
1997 & 0 & 8.9 & 0 & 0 & 0 & 4.4 & 4.9 & 4 & 0 & 0 & 4.9 & 9.2 & 36.3 \\
1998 & 0 & 0 & 0 & 0 & 7.6 & 9.3 & 0 & 0 & 0 & 0 & 0 & 0 & 16.9 \\
1999 & 0.2 & 5 & 0 & 0 & 0 & 4.9 & 0.1 & 2.4 & 4 & 0 & 0.1 & 0 & 16.7 \\
2000 & 0 & 0 & 0.1 & 0 & 0 & 0.1 & 0 & 9.3 & 0 & 14.8 & 0 & 0 & 24.3 \\
2001 & 0 & 0 & 12.8 & 10.4 & 0 & 4.3 & 0 & 0 & 0 & 4.9 & 8 & 12.5 & 52.9 \\
2002 & 9 & 0 & 8.1 & 4 & 27.6 & 0 & 16.3 & 0 & 2.3 & 0 & 0 & 0 & 67.3 \\
2003 & 4.9 & 0 & 4 & 0 & 10.3 & 4.4 & 0 & 0 & 0 & 0 & 0 & 18.1 & 41.7 \\
2004 & 0 & 0 & 26.8 & 5 & 0 & 0 & 2.2 & 0.3 & 0 & 0 & 4.8 & 14 & 53.1 \\
& & & & & & & & & & & & & \\
\hline
\end{tabular}

Note: Total conflict from China towards Japan was 623 units and total conflict from Japan towards China was 530 units over the period 
Asia Pacific Economic Papers

\section{Previous Asia Pacific Economic Papers}

385 Japanese Aid as a prerequisite for FDI: the case of Southeast Asian countries Séverine Blaise, 2009

384 Insular Decision-making in the Board Room: Why Boards Retain and Hire Sub-Standard CEOs Meg Sato, 2009

383 How does Financial System Efficiency Affect the Growth Impact of FDI in China? Ying $X u, 2009$

382 A Tale of Pork Prices: Evasion and Attenuation of a Japanese Tariff Kazuki Onji, 2009

381 Are the East Asian Currencies Still Misaligned? An Analysis Based on Absolute ppp-Income Relationship using Panel Data

Taizo Motonishi, 2009

380 Is Foreign Aid a Vanguard of Foreign Direct Investment? A Gravity-Equation Approach Hidemi Kimura and Yasuyuki Todo, 2009

379 Rain, Elections and Money: The Impact of Voter Turnout on Distributive Policy Outcomes in Japan Yusaku Horiuchi and Jun Saito, 2009

378 Japanese FDI in China: determinants and performance Shiro Armstrong, 2009

377 Expansion Abroad and Jobs at Home: Evidence from Japanese Multinational Enterprises Nobuaki Yamashita and Kyoji Fukao, 2009

376 Should Australia Encourage Developing Countries to Adopt Competition Laws? Henry Ergas, 2008

375 Will New Trends in Foreign Direct Investment Change the Structure of Intra-industry Trade between China and Japan?

Tao Tao, 2008

374 Competition Policy in ASEAN: Case studies Johannah Branson, 2008

373 Can the New Antimonopoly Act Change the Japanese Business Community? The 2005 Amendment to Antimonopoly Act and Corporate Compliance.

Kazukiyo Onishi, 2008

372 Immunising future trade against protectionists: preventing the emergence of more sensitive sectors Andrew Elek, 2008

371 Tax law asymmetries and income shifting: evidence from Japanese Capital KEIRETSU Kazuki Onji and David Vera, 2008

370 The response of firms to eligibility thresholds: evidence from the Japanese value-added tax Kazuki Onji, 2008

369 China and East Asian Energy: Prospects and Issues Vol. 1 \& 11 Peter Drysdale, Kejun Jiang and Dominic Meagher, 2008

368 Measuring trade and trade potential Shiro Armstrong, 2007

367 APEC and infectious disease: meeting the challenge Joel Gilbourd, 2007

366 The flow of funds through a government - A case study on Japan Jun Ikeda, 2007

365 The puzzle of small farming in Japan Yoshibisa Godo, 2007

364 How should one evaluate fiscal conditions? A study based on the comparison between Japan and Australia 
Annual subscription rate for up to eight issues:

Individuals A $\$ 65.00$ (includes GST) A \$60 (overseas)

Institutions A\$110.00 (includes GST) A \$100 (overseas)

\title{
Cost for single issues:
}

\author{
A $\$ 16.50$ (includes GST) A $\$ 15.00$ (overseas) \\ A $\$ 10.00$ (Students) \\ No postage required within Australia
}

Available from:

Centre Administrator

Australia-Japan Research Centre

Crawford School of Economics and Government

ANU College of Asia and the Pacific

The Australian National University

Canberra ACT 0200, Australia

Facsimile: (61 2) 61258448

Telephone: (61 2) 61253780

Email: ajrc@anu.edu.au

URL: http://www.crawford.anu.edu.au 